\title{
PERANAN NEGARA TERHADAP PENETAPAN HARGA ALAT KESEHATAN DETEKSI COVID - 19 PADA MASA PANDEMI
}

\section{Hamzah Haikal Riziq Alwi Alatas, Ferdinand Nicholas, Maria Cecilia Nugroho, Imelda Martinelli}

\author{
${ }^{1}$ Jurusan Ilmu Hukum, Universitas Tarumanagara Jakarta \\ Email: Hamzahalattas21@gmail.com \\ 2 Jurusan Ilmu Hukum, Universitas Tarumanagara Jakarta \\ Email: syilvia3456@gmail.com \\ ${ }^{3}$ Jurusan Ilmu Hukum, Universitas Tarumanagara Jakarta \\ Email: mariacecilianugroho@gmail.com \\ ${ }^{4}$ Dosen Pembimbing, Universitas Tarumanagara Jakarta \\ Email: imeldam@fh.untar.ac.id
}

\begin{abstract}
The significant increase in the number of Covid-19 cases from December 2020 to June 2021 has forced Indonesia to implement PPKM to date. Therefore, people are increasingly worried about leaving the house, especially for those who have to go to work, meet important people, return to their hometowns, and various other important activities. $P C R$ is the answer and requirement for people who want to do important activities outside the home. However, the PCR test itself makes the public even more hesitant in carrying out the PCR test because the price is too high for the Indonesian people. The purpose of this study itself is to find out how the pricing policy of medical devices is seen from the perspective of the community and understand what are the factors that make medical devices and medicines expensive. Therefore, we conducted studies and research on government policies regarding medical devices that are still controversial as well as the pros and cons of pricing medical devices for Covid-19 detection. This type of research is normative legal research whose implementation is focused on collecting secondary data. This study concludes that the policies made by the government in determining the price of PCR are still not accessible to most Indonesians. The government should make new policies that are relevant for all Indonesian citizens in determining the price of PCR, medicines, and other medical devices. Factors that decrease the price of medical equipment itself are caused by the pressure and pressure experienced by the community. The community requested that the lowered price be affordable for all people without discriminating because all of them have the same rights in this regard, especially health. The quality of medical devices provided and provided is the best for the Indonesian people because the better the quality, the more people believe in the Covid-19 diagnostic test so that tracking, checking and treatment can reach all people quickly and responsively. The rights of Indonesian citizens in health must be fulfilled during this pandemic, as is the obligation of the state to protect its citizens without exception.
\end{abstract}

Keywords: Covid - 19, PCR, Pricing Policy, Health

\begin{abstract}
ABSTRAK
Meningkatnya angka kasus Covid - 19 secara signifikan sejak bulan Desember 2020 sampai juni 2021 membuat Indonesia harus melaksanakan PPKM sampai saat ini. Oleh karena itu masyarakat semakin khawatir untuk keluar rumah terutama bagi mereka yang harus pergi bekerja, bertemu orang penting, pulang kampung, dan berbagai kegiatan penting lainnya. PCR adalah jawaban dan syarat bagi masyarakat yang mau melakukan aktivitas diluar rumah yang penting. Namun tes PCR sendiri yang membuat masyarakat semakin bimbang dalam melakukan tes PCR disebabkan harga yang terlalu bagi masyarakat Indonesia. Tujuan penelitian ini sendiri adalah mengetahui bagaimana kebijakan penetapan harga alat kesehatan dilihat dari perspektif masyarakat dan memahami apa yang menjadi faktor-faktor mahalnya alat kesehatan maupun obat-obatan. Maka dari itu, kami melakukan studi dan penelitian tentang kebijakan pemerintah mengenai alat kesehatan yang masih kontroversi maupun pro dan kontra dalam masalah penetapan harga alat kesehatan deteksi Covid - 19. Jenis penelitian ini adalah penelitian hukum normatif yang pelaksanaanya difokuskan pada pengumpulan data sekunder. Penelitian ini menyimpulkan kebijakan yang dibuat pemerintah dalam penetapan harga PCR masih belum bisa dijangkau oleh sebagian besar masyarakat Indonesia. Pemerintah seharusnya membuat kebijakan baru yang relevan untuk semua warga Indonesia dalam penetapan harga PCR, obat-obatan, maupun alat kesehatan lainnya. Faktor-faktor menurunnya harga alat kesehatan sendiri itu disebabkan oleh desakan dan tekanan yang dialami masyarakat. Masyarakat meminta agar harga yang diturunkan bisa dijangkau oleh semua masyarakat tanpa membeda-bedakan karena semuanya mempunyai hak yang sama didalam hal ini khususnya kesehatan. Kualitas alat kesehatan yang diberikan dan disediakan adalah yang terbaik untuk masyarakat Indonesia karena semakin baik kualitasnya maka banyak masyarakat yang percaya akan
\end{abstract}


tes diagnosa Covid - 19 sehingga pelacakan, pengecekan dan perawatan bisa merangkul semua masyarakat dengan cepat dan tanggap. Hak warga negara Indonesia dalam kesehatan harus dipenuhi dalam masa pandemi ini sebagaimana kewajiban negara dalam melindungi warga negaranya tanpa terkecuali.

Kata Kunci: Covid - 19, PCR, Kebijakan Penetapan Harga, Kesehatan

\section{PENDAHULUAN}

\section{Latar Belakang}

Tujuan negara adalah menjadi suatu dasar dalam membimbing dan mengatur kehidupan masyarakat. Tujuan negara Republik Indonesia tercantum didalam Pembukaan UUD 1945 yang berbunyi" Melindungi segenap bangsa Indonesia dan seluruh tumpah darah Indonesia, memajukan kesejahteraan umum, mencerdaskan kehidupan bangsa, melaksanakan ketertiban dunia yang berdasarkan kemerdekaan, perdamaian abadi dan keadilan sosial". Sekarangsekarang ini Indonesia sedang didalam masa pandemi Covid - 19 yang membuat tujuan negara harus diperkuat dan dilaksanakan secara baik dan tegas sesuai amanat UUD 1945.

Angka Covid - 19 meningkat secara signifikan (kompas.com) sejak bulan Desember 2020 sampai Juni 2021 (Muhammad Reza, 2021). Kasus Covid - 19 yang terus berkembang tentu membuat masyarakat luas makin resah. Hal ini bisa dilihat dengan adanya PPKM yang terus diperpanjang hingga sekarang dan diiringi dengan harga tes diagnosa Covid - 19 yang tinggi dan tidak memiliki kepastian. Hal ini telah menjadi polemik yang berkelanjutan dan menimbulkan banyak pertanyaan dari masyarakat Indonesia (cnnindonesia.com).

Kebijakan pemerintah mengenai penetapan harga tes diagnosa Covid - 19 dianggap tidak tegas dan tidak menunjukan keberpihakan terhadap masyarakat yang saat pandemi mengalami keterpurukan ekonomi akibat maraknya PHK dan sulitnya menjalankan kegiatan usaha khususnya sektor UMKM. Menurut Benny K. Harman selaku anggota DPR RI (suara.com) daftar melambungnya harga tes disebabkan karena niat pemerintah yang ingin meraup untung di masa pandemi ini. Harga tes PCR (polymerase chain reaction) yang dibandrol seharga Rp 900.000 menimbulkan banyak kritik dari masyarakat. Hal ini dianggap membebankan masyarakat. Terlebih bagi masyarakat yang sumber mata pencahariannya membutuhkan tes PCR. Jika dibandingkan dengan harga tes PCR di India, yaitu dimana harga tes PCR dibandrol seharga Rp 96.000, membuktikan bahwa harga tes PCR yang beredar di Indonesia tergolong tinggi. Perbedaan selisih harga yang besar ini menimbulkan tanda tanya besar dari masyarakat. Masyarakat yang merasakan bahwa ada keanomalian dalam kebijakan penetapan harga test diagnosa Covid - 19 mulai memberikan berbagai argumen dan kritik melalui sosial media yang secara tidak langsung ditujukan untuk pemerintah.

Penetapan harga tes diagnosa Covid - 19 yang tertera pada Surat Edaran Kementerian Kesehatan RI Nomor: HK.02.02/I/3713/2020 membuat masyarakat terbebani untuk melakukan tes PCR (Faisal Herisetiawan Jafar, 2021). Penetapan harga PCR yang belum pasti juga mengakibatkan banyaknya perbedaan harga tes di berbagai lokasi. Hal ini menjadi salah satu faktor meningkatnya angka Covid - 19 karena masyarakat tidak mendapatkan kepastian. Pemerintah yang memiliki tanggung jawab untuk mengambil keputusan yang terbaik untuk masyarakat, sudah mulai bergerak untuk mengatasi hal ini dari akarnya, dimulai dengan dikeluarkannya Surat Edaran Kementerian Kesehatan RI Nomor: HK.02.02/I/2845/2021 yang berisi tentang penurunan harga tes PCR.

\section{Rumusan Masalah}

Berdasarkan latar belakang penelitian tentang peranan negara terhadap penetapan harga alat kesehatan deteksi Covid - 19 diatas, maka bisa dirumuskan beberapa masalah seperti berikut ini 1). Bagaimanakah peran pemerintah dalam menetapkan harga tes diagnose Covid -19?

2). Faktor apa yang membuat menurunnya harga tes diagnosa Covid -19 ? 


\section{METODE PENELITIAN}

Dalam penulisan mengenai pernanan negara terhadap penetapan harga tes diagnosa Covid - 19 pada masa pandemi ini menggunakan metode penelitian hukum normatif yang pelaksanaanya difokuskan pada pengumpulan data sekunder ( bahan Pustaka ) yang meliputi bahan hukum primer seperti peraturan perundang-undangan, bahan hukum primer seperti buku, artikel, dan sebagainya. Penelitian ini bersifat deskriptif yang bertujuan untuk memberikan gambaran data yang selengkap-lengkapnya mengenai peranan negara terhadap penetapan harga alat kesehatan. Penelitian ini menggunakan pendekatan/paradigma kualitatif untuk mendapatkan pemahaman terhadap gejala-gejala yang diteliti. Data diolah dan di analisis secara kualitatif dengan menggunakan logika deduktif dengan menempatkan peraturan perundang-undangan dan peraturan kebijakan sebagai premis mayor dan fakta-fakta sebagai premis minor untuk selanjutnya di tarik suatu kesimpulan sesuai permasalahan yang di kaji.

\section{HASIL DAN PEMBAHASAN}

\section{Penetapan harga tes diagnosa Covid - 19}

Merujuk ketentuan Pasal 40 Ayat 6 UU No. 36 Tahun 2009 tentang Kesehatan yang menetapkan bahwa perbekalan Kesehatan berupa obat generik yang termasuk dalam daftar obat esensial nasional harus dijamin ketersediaan dan keterjangkauannya, sehingga penetapan harganya dikendalikan oleh pemerintah. Kata keterjangkauan pada ketentuan tersebut meneguhkan bahwa pemerintah punya kewajiban untuk menetapkan harga obat yang sesuai dengan kemampuan finansial warga masyarakat. Walaupun penjelasan Pasal 40 tidak menjabarkan lebih lanjut tentang ayat yang dimaksud, dalam penjelasan umum dikemukakan bahwa persoalan Kesehatan merupakan faktor utama yang merupakan investasi berharga yang menjelaskan paradigma sehat yang mengutamakan upaya promotif dan preventif tanpa mengabaikan kuratif dan rehabilitatif.

Pandemi Covid - 19 membuat segala sesuatunya sulit dilakukan dan terbatas segala aktivitas yang ingin masyarakat lakukan sehingga pemerintah memutuskan untuk melakukan tes PCR baik itu berpergian, melakukan pekerjaan, bertemu dengan orang penting dan apapun yang berhubungan dengan aktivitas luar membutuhkan hasil tes Covid - 19. Diantaranya tes PCR sebagai suatu metode pemeriksaan apakah seseorang didapati virus Covid - 19 dengan mendeteksi DNA virus. Hasil metode ini akan mendapatkan apakah seseorang positif/negatif. Pemeriksaan PCR sendiri lebih akurat dibanding metode yang lain. Namun harga PCR pada tahun 2020 sangat mahal sehingga menyentuh harga 1 juta. Suatu harga yang terlalu mahal bagi warga Indonesia, oleh karena itu harga yang diberikan diturunkan menjadi Rp. 900.000 dan bahkan sudah ditentukan menjadi harga tetap di Surat Edaran Menteri Kesehatan Nomor HK.02.02/I/3713/2020.

Sekalipun harga yang ditentukan oleh pemerintah itu sudah memperkirakan bahwa ini sepadan dengan kemampuan warga negara Indonesia, justru masyarakat Indonesia masih tetap diberatkan. Bagaimana tidak, masyarakat Indonesia tidak hanya populasinya hanya orang menengah kelas atas/orang-orang superior saja namun ada masyarakat-masyarakat menengah ke bawah dan kecil yang mencari sesuap nasi saja sudah susah apalagi ditambahnya dengan pandemi. Oleh karena itu dikeluarkannya Surat Edaran Kementerian Kesehatan RI nomor: HK.02.02/I/2845/2021 tentang batas tarif tertinggi pemeriksaan PCR. Diketahui bahwa harga PCR itu sebelumnya Rp. 900.000 diubah menjadi Rp. 495.000 untuk pulau Jawa dan Bali, untuk diluar pulau Jawa dan Bali di tarif sebesar Rp. 525.000.

Ada beberapa aspek yang mempengaruhi mengapa harga alat Kesehatan deteksi Covid - 19 berbeda dari surat edaran Kementerian Kesehatan. Semua fasilitas kesehatan di Indonesia di daerah manapun mempunyai kelengkapannya tersendiri mulai dari mesin uji yang mahal, bahan dan alat yang masih bergantung pada impor dari luar negeri, APD yang hanya dipakai 1 kali dan harus dibeli lagi, sarana membuang limbah, dan jasa dokter dan analisis. Selama ini masyarakat 
masih membeli hampir semua aspek dari impor dan itu masih harga yang lama. Sehingga untuk mengikuti ketetapan pemerintah cukup sulit untuk menurunkan harga tes PCR. Alat yang dibeli dari Eropa, bahan yang terbilang sangat baik juga membuat para pelaku usaha bingung untuk menurunkannya. Terakhir mengenai alat tes yang bisa mengeluarkan hasil dalam waktu 2 jam dan 8 jam. Sehingga semakin cepat hasil yang ingin didapat maka ada harga lebih yang harus dibayar sesuai ketentuan fasilitas kesehatan yang ada.

Di Indonesia, jaminan yuridis terhadap hak atas kesehatan telah ada sejak diberlakukannya Konstitusi Republik Indonesia Serikat (RIS) tahun 1949. Pada Pasal 40 Konstitusi RIS dijelaskan bahwa "Penguasa senantiasa berusaha dengan sungguh-sungguh memajukan kebersihan umum dan kesehatan rakyat "(Muhamad Beni Kurniawan, 2021). Dari pasal tersebut kata "penguasa" disini ditunjukan kepada pemerintah,pejabat dan superior yang seharusnya membantu rakyat dalam melawan dan mengatasi pandemi covid - 19 bersama sama. Namun, itu tidak seindah dengan kata pasal yang ditafsirkan. Banyak para pejabat, para penguasa yang sewenangwenangnya mengambil keuntungan didalam kesempitan bahkan situasi yang genting ini. Mereka mengambil keuntungan dari hasil korupsi pengadaan alat kesehatan bahkan sampai merugikan negara sebesar Rp.14,1 miliar dan membagikan hasil korupsi pengadaan tersebut kepada rekan dan perusahaan yang berkerja sama dengan oknum (kompas.com). Alat kesehatan sendiri terdiri dari tabung oksigen, obat-obatan, masker dan lain-lain. Para pelaku penimbunan alat kesehatan sengaja melakukannya agar bisa menaikkan harga bahkan berlipat kali dari harga normal menjadikan sebuah keuntungan besar bagi para oknum. Dalam tafsiran ini menjelaskan bahwa tidak semua penguasa itu mementingkan kebutuhan masyarakatnya. Bagi mereka para pejabat yang mengakali harga tes PCR/ fasilitas kesehatan yang masih tidak menetapkan harga sesuai dengan Surat Edaran Kementerian Kesehatan RI nomor: HK.02.02/I/2845/2021, maka akan sanksi bagi mereka yang melanggarnya dan yang berwenang mengatur sanksinya adalah dinas kesehatan kabupaten/kota setempat dan kementerian kesehatan.

Fondasi utama yakni perlindungan HAM merupakan suatu kewajiban negara dan pemerintah dalam memajukan, melindungi dan memenuhi hak-hak warga negaranya khususnya kesehatan yang merupakan keharusan pemerintah untuk memenuhi hak-hak warga negara. Didalam Pasal 28 I ayat (4) UUD 1945 menyatakan bahwa perlindungan, pemajuan, penegakan, dan pemenuhan hak asasi manusia adalah tanggung jawab negara, terutama pemerintah. Bukan hanya negara saja yang turun tangan dalam membantu menangani pandemi Covid - 19 ini namun turunannya yaitu pemerintah juga harus membina dan menunjukkan bahwa tanggung jawab negara dan pemerintah kepada masyarakat Indonesia sungguh besar dalam melawan pandemi ini khususnya masalah kesehatan. Kewajiban dan tanggung jawab negara dan pemerintah diatur didalam Undang-Undang Pasal 6-9 Nomor 23 Tahun 1992 tentang kesehatan mengenai tugas dan tanggung jawab pemerintah dalam mengatur, membina, dan menyelenggarakan upaya kesehatan yang merata dan terjangkau oleh masyarakat bahkan sampai masyarakat yang kurang mampu tetap terjamin hak dalam memperoleh derajat kesehatan yang optimal sesuai Undangundang Pasal 4 Nomor 23 Tahun 1992 tentang kesehatan mengenai hak warga negara. Upaya kesehatan disini artinya merata ke semua warga negara bahkan sampai ke daerah terpencil termasuk orang yang kurang mampu, orang terlantar, dan fakir miskin dengan mengupayakan yang terbaik untuk masyarakatnya dalam menghadapi pandemi Covid - 19. Pemerintah tidak hanya bekerja dalam mencegah terjadinya pelanggaran dalam penetapan harga yang tidak sesuai namun bagaimana pemerintah dan negara bekerja sama dalam menyediakan dan melayani masyarakat yang terdampak pandemi Covid - 19. Negara dan pemerintah harus memperhatikan, menjalankan dan mengamalkan sebagai amanat yang tertulis didalam UUD 1945 Pasal 28H ayat (1) "Setiap orang berhak hidup sejahtera lahir dan batin, bertempat tinggal, dan mendapatkan lingkungan hidup yang baik dan sehat serta berhak memperoleh pelayanan kesehatan." Disini terdapat hak warga negara yang tidak hanya menyangkut soal mendapat obat maupun alat 
kesehatan yang dibutuhkan tetapi masyarakat juga memperoleh pelayanan kesehatan yang adil dan merata tanpa membedakan status sosial maupun tingkatan ekonomi.

Pasal 7 UU No. 6 tahun 2018 tentang kekarantinaan Kesehatan, ditegaskan bahwa setiap orang memiliki hak memperoleh perlakuan yang sama dalam penyelenggaran kekarantinaan Kesehatan. Yang dimaksud dengan " Perlakuan yang sama " adalah bahwa dalam penyelenggaraan kekarantinaan Kesehatan tidak boleh bersifat diskriminatif atau membeda bedakan perlakuan. Tidak dipungkiri bahwa pemerintah telah berupaya maksimal dalam penanggulangan Covid -19. Dimana para korban mendapatkan perlakuan khusus diberbagai rumah sakit atau di tempat lain yang dijadikan sebagai rumah sakit darurat. Pada saat puncak pandemi, banyak warga masyarakat yang tidak berhasil mendapatkan perawatan gratis yang diberikan oleh pemerintah. Tidak sedikit warga masyarakat yang mengupayakan tarif tes diagnosa akan juga biaya perawatan secara mandiri. Dalam hal ini ditemukan kasus perbedaan harga perawatan pasien Covid - 19 .

\section{Faktor-faktor yang membuat turunnya harga alat kesehatan deteksi Covid - 19}

Faktor yang menyebabkan harga yang turunnya PCR itu karena desakan dan tekanan yang dialami masyarakat. Sebelumnya pemerintah selalu mengevaluasi secara periodik mengenai ketentuan batas tarif tertinggi sebesar Rp.900.000 dinilai tidak meningkat/menurunnya aktivitas tes PCR oleh masyarakat. Ini menyebabkan pemerintah harus menetapkan harga yang sesuai dan relevan kepada semua masyarakat. Apalagi hampir semua masyarakat Indonesia adalah pekerja keras/yang mengharuskan masyarakat bekerja secara nyata di luar rumah. Sehingga tracing(pelacakan), testing(pengecekan), treatment(perawatan) terlaksana secara baik. Oleh karena itu, Presiden Jokowi meminta harga turun menjadi Rp. 450.000 sampai Rp. 525.000 dan hasil yang didapatkan dari tes tersebut maksimal 1x24 jam sehinggga semakin banyak masyarakat yang mau melakukan tes demi keselamatan bersama. Pengendalian pandemi Virus Covid - 19 di Indonesia tidak bisa hanya dilihat dari rumah sakit yang memadai/lengkap, namun sumber daya manusia yang berkualitaslah yang harus juga diperhatikan.

Namun bukan berarti dengan harga yang diturunkan menjadikan suatu kualitas tes menurun. Justru tiga organisasi yang terdiri dari Perhimpunan Rumah Sakit Seluruh Indonesia(Persi), Ikatan Laboratorium Kesehatan Indonesia(ILKI), serta Perkumpulan Organisasi Perusahaan Alat-Alat Kesehatan dan Laboratorium Indonesia atau Gakeslab Indonesia menyatakan suatu komitmen untuk terus menjaga kualitas hasil pemeriksaan PCR. Menjaga kualitas melalui penyediaan teknologi yang baik dan penggunaan bahan reagen yang bermutu tinggi. Masyarakat sendiri bisa mendapatkan hasilnya yang memenuhi kaidah K4 (Keamanan, Kualitas, Kinerja dan Ketersediaan).

\section{KESIMPULAN DAN SARAN}

Sesuai amanat Pasal 40 Ayat 6 No. 36 Tahun 2009 Undang-undang tentang Kesehatan bahwa semua produk kesehatan baik itu obat-obatan maupun tes diagnosa Covid - 19 perlu dijamin ketersediaan dan keterjangkauannya sehingga penetapan harga dikendalikan dan ditetapkan oleh pemerintah sesuai dengan kemampuan masyarakat Indonesia, dengan tidak sewenangwenangnya memutuskan kebijakan penetepan harga yang dapat menjadi beban bagi masyarakat. Penetapan harga sendiri sudah diatur didalam Surat Edaran Kementerian Kesehatan RI nomor: HK.02.02/I/2845/2021 yang harus dipatuhi selama tidak ada perubahan mengenai penetapan harga PCR. Penetapan harga yang dilakukan negara dan lembaga kesehatan sudah berjalan baik namun masih ada oknum-oknum yang mengambil keuntungan dari masa pandemi seperti ini. Oleh karena itu, pemerintah harus menjalankan apa yang menjadi kewajibannya sebagaimana hak warga negara yang harus dipenuhi. Tanpa membeda-bedakan kelas ekonomi maupun status sosial yang dimiliki masyarakat, semuanya wajib diperhatikan dan dipenuhi hak kesehatan 
mereka. Peranan pemerintah dalam menetapkan harga tes diagnos Covid - 19 sangat baik dalam hal menurunkan harga tes PCR yang sedikit membantu masyarakat Indonesia dalam meringankan bebannya dan sudah ketat didalam pengawasan harga di setiap pelayanan dan fasilitas kesehatan yang ada di seluruh Indonesia.

Desakan dan tekanan yang dialami masyarakat dalam hal ekonomi yaitu menjadi salah satu faktor mengapa harga penetapan tes PCR menurun. Dikarenakan hampir semua masyarakat Indonesia adalah pekerja yang mengharuskan bekerja di luar rumah secara luring menjadi salah satu faktor berubahnya harga tes diagnosa Covid - 19 yang awalnya Rp.900.000 menjadi Rp. 450.000 sampai Rp. 525.000. Walaupun harga alat kesehatan menjadi menurun tetapi kualitas yang diberikan dan digunakan tetap yang terbaik, sehingga masyarakat Indonesia tidak perlu khawatir akan kualitas alat kesehatan di Indonesia sebagaimana itu menjadi komitmen para lembaga kesehatan. Pemerintah juga sudah melakukan apa yang mereka bisa atas penurunan harga tersebut yang dimana pemerintah juga mengorbankan berbagai pihak dalam penanganananya. Pemerintah dan masyarakat perlu bekerja sama sehingga terjadi keseimbangan antara kedua pihak tanpa

Oleh karena itu masyarakat juga perlu menyadari bahwa segala sesuatu yang berhubungan dengan keramain pasti merujuk kepada tes PCR yang segala sesuatu nya harus di persiapkan. Pemerintah juga sudah melakukan apa yang mereka bisa atas penurunan harga tersebut yang dimana pemerintah juga mengorbankan berbagai pihak dalam penanganananya. Pemerintah dan masyarakat perlu bekerja sama sehingga terjadi keseimbangan antara kedua pihak tanpa merugikan satu sama lain. Indonesia adalah negara kesatuan yang dimana setiap warga negaranya bisa bersatu dalam mengatasi persoalan yang dihadapi di negeri ini. Ada hak warga negara yang harus dipenuhi dan ada peranan negara dalam melaksanakan kewajiban mereka di masa pandemi ini.

Berdasarkan permasalahan-permasalahan yang telah diuraikan, maka dengan di adakanya penurunan harga tes PCR tersebut, pemerintah juga harus sadar bahwa harga tersebut juga dapat menambah beban bagi masyarakat. Mengapa? Karena Indonesia masih ketergantungan dalam bahan dan alat tenaga medis yang diperlukan sekarang ini. Pemerintah perlu tetap memperhatikan kepentingan publik yaitu masyarakat yang sedang mengalami sulitnya mencari uang demi kelanjutan hidupnya yang mengharuskan bekerja secara nyata sehingga pemerintah dapat membuat kebijakan yang baru dan relavan bagi semua masyarakat Indonesia. Pemerintah akan terus berupaya dalam membuat kebijakan dalam hal penurunan harga PCR, obat-obatan maupun alat kesehatan lainnya sehingga memudahkan semua warga masyarakat yang membutuhkan dan bagi tenaga medis.

Diketahui bahwa memerlukan waktu dan persiapan yang matang, namun masyarakat tetap mendukung apapun kebijakan yang dibuat pemerintah yang bisa membuat Indonesia bergerak kembali sehingga pemerintah bisa mengurangi impor dan bisa menekan harga PCR untuk semua masyarakat Indonesia. Masyarakat mengharapkan pemerintah sadar akan gejolak yang terjadi karena fenomena ini, jangan sampai yang menjadi korban adalah pihak pihak tenaga dibidang kesehatan hanya karena harga PCR turun tenaga kesehatan pun ikut turun gajinya. Masyarakat prihatin kepada mereka yang sudah mengorbankan jiwa raganya demi keselamatan satu nyawa saja dan sudah melakukan yang terbaik selama 1x24 jam. Kiranya pemerintah dapat memperhatikan kondisi tenaga kesehatan yang sudah berjuang keras karena persoalan ini. Pemerintah juga perlu menjaga masyarakatnya tetap sehat dan dapat mencukupi kebutuhan mereka disaat keadaan yang sangat sulit seperti ini. Memperhatikan keperluan masyarakat adalah suatu kewajiban bagi pemerintah untuk membangun kembali Indonesia menjadi negara yang bangkit dari pandemi Covid - 19. Semoga Indonesia bisa cepat pulih.

\section{Ucapan Terima Kasih}




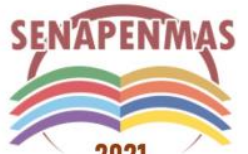

2021
Seminar Nasional Hasil Penelitian dan Pengabdian Kepada Masyarakat 2021 Pengembangan Ekonomi Bangsa Melalui Inovasi Digital Hasil Penelitian dan Pengabdian Kepada Masyarakat Jakarta, 21 Oktober 2021

Segala puji dan syukur kami panjatkan ke hadirat Tuhan Yang Maha Esa atas berkat dan rahmatnya selama kami mengerjakan artikel ilmiah ini. Penulisan artikel ini dibuat dengan tujuan agar orang dapat mengetahui suatu isu yang terjadi di antara masyarakat Indonesia.

Kami menyadari bahwa artikel ilmiah ini tidak akan selesai tanpa bantuan dan dukungan dari berbagai pihak. Maka dari itu dengan segala kerendahan hati, izinkan kami mengucapkan terima kasih yang sedalam - dalamnya kepada :

1. Bapak Yuwono Prianto S. H. , M. H. selaku pembimbing kami dalam proses penulisan artikel ilmiah

2. Keluarga kami sebagai orang - orang yang mendukung kami untuk menulis artikel ilmiah.

3. Seluruh anggota kelompok selaku penulis dari artikel ilmiah ini.

\section{REFERENSI}

Al Faqir, Anisyah. ( 2020 ). Pemerintah Ungkap Penyebab Harga Tes PCR Corona Mahal. Merdeka.com.

Alika, Rizky. ( 2020 ). Patok Harga Tes PCR Rp 900 Ribu, Kemenkes Ancam RS yang Tak Patuh. Katadata.co.id.

Basith Bardan, Abdul. ( 2021 ). ICW: Saat ini penetapan harga tes PCR tidak menunjukkan keterbukaan kepada masyarakat. Kontan.com

Beni Kurniawan, Muhamad. ( 2021 ). Politik Hukum Pemerintah dalam Penanganan Pandemi Covid - 19 Ditinjau dari Perspektif Hak Asasi atas Kesehatan. Balitbangham.go.id.

Biro Komunikasi. ( 2021 ). PPKM Level Empat dan Tiga Diberlakukan Mulai 26 Juli - 2 Agustus 2021, Menko Luhut: Rapatkan Barisan Demi Pemulihan Bersama.

CNN Indonesia ( 2020 ). Penyebab Tes Swab PCR Lebih Mahal dari Rapid Tes Antibodi. CNN Indonesia.

CNN Indonesia. ( 2021 ). Polemik Harga Selangit PCR, Direvisi usai Dikritik Netizen.CNN Indonesia.

Fanani, Faizal. ( 2021 ). Penurunan Harga Tes PCR Diharapkan Tak Mengurangi Kualitas Hasil. Merdeka.com.

Gunadha, Reza. ( 2021 ). Sentil Pemerintah, Benny: Jangan Ambil Untung, Kapan PCR Gratis untuk Rakyat?. Suara.com.

Halim, Devina. ( 2021 ). Kasus Pengadaan Alkes Unair, Mantan Pejabat Kemenkes Didakwa Rugikan Negara Rp 14,1 Miliar. Kompas.com.

Herisetiawan Jafar, Faisal. ( 2021 ). Tinjauan Hukum Pemberlakuan Harga Rapid Test Antigen dan Swab PCR. Jurnal Untidar.

Kadir, Abdul. ( 2020 ). SE Tentang Batasan Tarif Tertinggi Pemeriksaan RT-PCR. Kemkes.go.id.

Karno, Dharma. ( 2021 ). Peran Pemerintah dan Tenaga Kesehatan dalam Penanggulangan Covid - 19. Jurnal Ilmiah STIKES Kendal.

Kartika Dewi, Retia. ( 2021 ). Tarif Tes PCR Turun Jadi Rp 450.000, Apa Penyebabnya?. Kompas.com.

Oktavia Erwanti, Marlinda. ( 2021 ). Harga Tes PCR di India Cuma Rp 96 Ribu, di Indonesia Rp 900 Ribu. Detik.com.

Puspa Sari, Hayanti. ( 2021 ). Kemenkes : Kasus Covid - 19 Meningkat 6 - 8 Kali Lipat Dibanding Desember - Januari. Kompas.com.

Rizki Bayu Kencana, Maulandy. ( 2021 ). HEADLINE: Indonesia Turun Jadi Negara Menengah Kebawah, Strategi Angkat Kembali. Liputan 6.com.

Tim Detik. ( 2021 ). Ditjen Pajak Jawab Polemik Harga PCR di RI. Detik.

Tim Detik. ( 2021 ). Kemenkes Jelaskan Alasan Tarif PCR Baru di Luar Jawa-Bali Lebih Mahal. Detik.com 
Tim Yuridis ( 2021 ). Surat Edaran Kementerian Kesehatan RI Nomor: HK.02.02/I/2845/2021

Tentang Batas Tarif Tertinggi Pemeriksaan Reserve Transcription Polymerase Chain Reaction (RT-PCR). Kemenkes. 